Asian Diasporas 


$$
\text { , }
$$




\section{Asian Diasporas}

New Formations, New Conceptions edited by

Rhacel S. Parreñas and Lok C. D. Siu 
Stanford University Press

Stanford, California

$\Theta_{2007}$ by the Board of Trustees of the Leland Stanford Junior University.

All rights reserved.

No part of this book may be reproduced or transmitted in any form or by any means, electronic or mechanical, including photocopying and recording, or in any information storage or retrieval system without the prior written permission of Stanford University Press.

Library of Congress Cataloging-in-Publication Data

Asian diasporas : new formations, new conceptions / edited by Rhacel S. Parreñas and Lok C. D. Siu.

p. cm.

Includes bibliographical references and index.

ISBN 978-0-8047-5243-5 (cloth : alk. paper)-ISBN 978-0-8047-5244-2 (pbk. : alk. paper)

1. Asian diaspora. 2. Asians-Foreign countries. I. Parreñas, Rhacel Salazar. II. Siu, Lok C. D.

DS13.A75 2007

304.8095-dc22

2007026785

Typeset by Thompson Type in 10/14 Minion Pro 